form

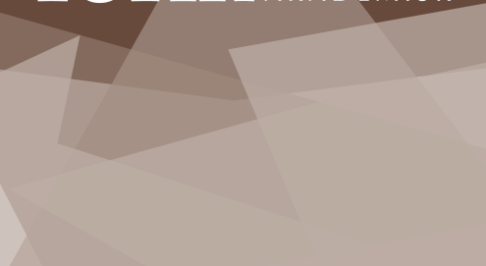

Irene Brodshaug

Assistant Professor

Oslo Metropolitan University, Norway irene.brodshaug@oslomet.no

Vol I4, No 4 (202I)

Janne Beate Reitan

Associate Professor (PhD)

Oslo Metropolitan University, Norway

janne.reitan@oslomet.no

\title{
Networking for strengthening design literacy $^{1}$
}

\begin{abstract}
This article focuses on design education for the general public and the ways in which students and teachers can become more design literate through the development of networks, such as professional groups for teachers. The aim of professional groups is to create a structure that focuses on design competency among Design, Art and Crafts teachers as well as design education in Norway's primary and secondary schools. Etienne Wenger's theories of community of practice and Unn Stålsett's theory about the development of networking through professional groups are highlighted in this study through the comparison of two municipalities in conjunction with informant interviews. The emphasis of this study is on how each municipality gives time and space for the development of design competence through professional groups. A well-organized professional group will hopefully contribute to a deeper level of expertise in schools and an increased ability for the general public to recognize design education.
\end{abstract}

Keywords:

design literacy, professional groups, strengthening lay people's competence, school development.

\section{INTRODUCTION}

In order to increase general awareness of which choices one must make for a sustainable future, several researchers have agreed that it is important to strengthen lay people's competence in the fields of design and sustainability (Nielsen \& Brænne, 2013; Pacione, 2010; Smith \& Iversen, 2018). In Norway's primary and lower secondary schools, where design is a primary focus area in the core curriculum, the subject of Art and Crafts is intended to advance design knowledge amongst students. In Norway, Design, Art and Crafts have been combined into one subject since 1960, first named Forming and from 1997 named Kunst og håndverk whereas in other countries these are most often separate subjects (Nielsen, 2008). Design, architecture, art and visual communication are core aspects of Norwegian curricula in Art and Crafts. This paper focuses on the part of the curriculum that deals with the design area in the 
subject of Art and Crafts. To make the role of deign within this subject, we choose to translate Kunst og håndverk in Norwegian to Design, Art and Crafts in English. We define design and design education broadly, in line with the journal FormAkademisk - research journal og design and design education, which include "fields such as industrial design, visual communication, interaction design, architecture, landscape architecture, urbanism and design education at all levels from kindergarden to the doctoral level" within their scope (FormAkademisk, 2021).

An example taken from the competence aims, stated in Norway's curriculum Kunnskapsløftet [Knowledge Promotion], indicates that students should be able to "design products based on a specification for form and function, describe the life cycle of a product, and assess implications for sustainable development, environmental impacts and utility" (Kunnskapsdepartementet [Ministry of Education], 2006, our translation from Norwegian). This policy document communicates that it is desirable that the general public receive design education. Its summary describes what students should learn in the field of design:

In design, the design of objects is central. Here, the craft tradition continues in the subject. Design includes both working directly with materials and working with sketches and models. The design of ideas, working drawings, products and forms of use are central. Knowledge of materials, problem solving, and production can form the basis for innovation and entrepreneurship. (Kunnskapsdepartementet [Ministry of Education], 2006, our translation from Norwegian)

In order for students in Norwegian schools to get the best possible education, they must have teachers with a high level of competence in their subject areas. A teacher of a foreign language, for example, is competent if they have a good command of the language, adequate writing skills and an understanding of the current culture. The teacher should also have a grasp of the language's literature. Similarly, a teacher who teaches design within the subject of Design, Art and Crafts must both be a competent practitioner and have the ability to teach the subject.

Teachers in Design, Art and Crafts come from different backgrounds. In our opinion, the aims for improving design competence are extensive and can be interpreted differently. There are several questions to ask within the context of this study:

- Does each primary school teacher have the skills necessary to offer their students a good design education?

- How can teachers strengthen their expertise and design literacy in the subject of Design, Art and Crafts?

- How can teachers develop a common understanding of what is important for their students to learn in order to develop competent decision-making and critical innovation skills?

- How should networking in professional groups be organized and managed in order to promote high-quality professional development for teachers?

These are important questions to reflect on in order for future citizens to become design literate.

\section{Previous research}

The study of Design, Art and Crafts is facing a number of challenges. Our current educational system focuses strongly on PISA (Programme for International Student Assessment) results in reading, mathematics and science. The Ministry of Education prioritizes funds for certain subject areas, effectively defining what is more or less important regarding the education of students in Norwegian schools (Brodshaug, 2016).

\section{Issues in the field of Design, Art and Crafts education in Norway}

- According to Lagerstrøm, Moafi, \& Revold's report Kompetanseprofil i grunnskolen, hovedresultater [Profile of Skills in Primary Schools, Main Results], based on Norwegian statistics, 
only half of all teachers who teach Design, Art and Crafts have a specialization in the subject (Lagerstrøm, Moafi, \& Revold, 2014; Kunnikoff, 2015).

- It is difficult to get a job as a specialized teacher in Design, Art and Crafts, and it is beneficial to have additional expertise in other subject areas (Kunnikoff, 2015).

- There are challenges with the current classroom framework, such as poorly functioning workshops or large class sizes (Hansen, 2015).

- There are challenges concerning the assessment of students (Lutnæs, 2011).

- The competency requirements in so-called "basic" subjects are promoted by The Ministry of Education but there are no competency requirements for Design, Art and Crafts at the primary level (Ministry of Education, 2015; Kunnikoff, 2015).

- There are fewer opportunities for teachers in Art and Crafts to pursue further education in their subject than there are for teachers in other subjects, like mathematics (Regjeringen [Government], 2015).

- There are few available textbooks and resources in the subject.

- School leaders perceive the subject of Design, Art and Crafts to be less important than other subjects (Lie, 2013).

- School days offer little relevant development time, and educators need to be able to collaborate with each other across subject areas (Garberg, 2014; Lie \& Nielsen, 2016).

Research in the area of Design, Art and Crafts highlights challenges involving a lack of cooperation among teachers of the subject, even though other studies illustrate the advantages of managing professional networks and pursuing collaborations (Brodshaug, 2016). Eva Lutnæs discusses collaboration in her doctoral thesis Standpunktvurdering i grunnskolefaget kunst og håndverk: Læreres forhandlingsreportoar [Final Evaluation Grades in the Subject of Design, Art and Crafts: the Teacher's Negotiation of Repertoire] (our translation from Norwegian). In her study, she examines two teams of teachers and focuses on how they collaborate while giving students their final grades. There are no requirements from the educational institutions for collaboration while teachers are grading (Lutnæs, 2011), however, Lutnæs's thesis reveals that teachers who collaborate have a more developed response when it comes to clarifying the reasons behind their final grades. Catrine Lie's 2013 master's thesis, Skolelederes verdsetting av læreres fagkompetanse i kunst og håndverk [School Leadership's Evaluation of Teachers' Subject Proficiency in Design, Art and Crafts] (our translation from Norwegian), addresses the issue of school leadership prioritising the hiring of teachers educated in the field of Design, Art and Crafts. Lie touches on the teaching loads of Design, Art and Crafts teachers and, specifically, their number of teaching hours, which is greater than the teaching loads of educators who teach other subjects in Norwegian schools (Lie \& Nielsen, 2016). She refers to Design, Art and Crafts teachers as a part of a collegium and describes the effects these teachers associate with collaboration and interdisciplinary work. According to Lie, the interviewees emphasised that having at least two teachers within the field of Design, Art and Crafts per school contributes a great deal to their job satisfaction and professional development (Lie, 2013). In her master's thesis, Formell fagkompetanse i kunst og handverk, Betydning, prioritering og konsekvenser [Formal Professional Competence in Design, Art and Crafts-Meaning, Prioritizing and Consequences] (our translation from Norwegian), June Kunnikoff writes that she consciously chooses to not spend very much time developing her professional network; however, she emphasises that networking is important to the participants of her research (Kunnikoff, 2015). Kunnikoff's study begins with statistics cited from Lagerstrøm et al.'s (2014) research, which shows that half of those teaching Design in Art and Crafts have no formal education in the subject (Lagerstrøm et al., 2014).

After having spoken with all five informants, I see in the transcripts that everyone speaks warmly about the professional collegium they have at school, and I get the impression that everyone places value on professional networks in different arenas. To varying degrees, collegiality is mentioned in schools, municipality-based professional network meetings, professional conferences, social media groups and 
the art and design education journal FORM as valuable for professional development and teaching. (Kunnikoff, 2015, p. 56, our translation from Norwegian)

Marit Garberg sheds light on the progress and development of local curricula in her master's thesis, Planer - hva og hvorfor? En undersøkelse av innholdet i de lokale læreplanene i kunst og håndverksfaget på barneskolens mellomtrinn [Plans-What and Why? An Examination of the Content of the Local Curricula in the Design, Art and Crafts Subject in Primary Schools] (our translation from Norwegian). She discusses lacklustre collaboration between schools and the lack of a guarantee that further education in the subject will be offered to Design, Art and Crafts teachers like for teachers in other subjects.

From my perspective and with my experience in the field, little collaboration exists among and between primary schools and lower secondary schools when it comes to the subject of Design, Art and Crafts, in contrast to other subjects, such as Norwegian and mathematics, in which established collaboration exists between primary and lower secondary schools. Here, I refer to schools that belong to the same school cluster. (Garberg, 2014, p. 15, our translation from Norwegian)

The Kjosavik report (2003) emphasises that specialized teachers in Design, Art and Crafts in primary and lower secondary schools collaborate less than classroom teachers in primary schools (Kjosavik, Koch, Skjeggestad, \& Aakre, 2003). The reasons for this can be complex. Teachers in Design in Design, Art and Crafts are often the solitary instructor at their school. This may be because the total number of class hours required in the subject is low, there are few classes offered in Design, Art and Crafts or the teachers are more focused on their own subject and find it less useful to work with other teachers and subjects (Brodshaug, 2016).

Current research is based on the question of whether there is a need to collaborate across schools in order to strengthen academic environments and heighten competence, as there are often only one or a few teachers in Design, Art and Crafts at each primary and secondary school.

\section{Research questions}

This paper discusses the following research questions: what content can academic networking groups for teachers in Design, Art and Crafts include, how can such groups be organized and what benefits does membership entail? In this research, design is both a core area of curriculum in the subject Design, Art and Crafts and a method for creating professional groups. Herbert Simon's definition of design is essential to our understanding of it; "Everyone designs who devises courses of action aimed at changing existing situations into preferred ones" (Simon, 1969, p. 55).

\section{METHOD}

This study is of an exploratory nature. Therefore, the qualitative method has been chosen to better explore how networking through professional groups can be organized for, as Alvesson and Sköldberg (2009) state, "Qualitative research is a contextual activity that places the viewer in the world. It consists of a set of interpretive, material practices that make the world visible" (p. 17).

Various professionals were interviewed for the study and two different municipalities in Norway were compared. Four informants from each of the participating municipalities were interviewed: an adviser of education in the municipality, the manager of the professional group, and two teachers that were members of a professional group. Their statements were then compared. The questions posed to the informants were designed to gain a deeper perspective on the content, organization and utility of professional groups within the field of Design, Art and Crafts. The questions posed to the informants were about the content, organization and utility value of professional groups. The study examined how the two municipalities, and their respective professionals, developed and manage the professional groups. The research explored-in-depth-field work done in Municipality 1, where the municipality systematizes the management of these groups. The manager of the professional groups in Municipality 2 was also interviewed. The manager, who is a teacher, has taken her own initiative concerning the professional groups and organizes meetings without the structure of a municipal model. Municipality 2 
is based on a model where enthusiasts drive the groups without the municipality's involvement, as is the case in Municipality 1. The research discusses Municipality 1's model for professional development through the professional groups and compares it with that of Municipality 2 (Brodshaug, 2016).

This research is based on a reflexive methodology (Alvesson \& Sköldberg, 2009), with a focus on a selection of a few theories, and makes use of Etienne Wenger's theory of communities of practice (Wenger, 1998; Wenger, McDermott, \& Snyder, 2002 ) and the theory for the structure of professional groups as described in the book Guidance in a Learning Organization (Stålsett, 2006).

\section{Interpretation perspectives Etienne Wenger}

Etienne Wenger (1998) and his older colleague Jean Lave developed the concept of communities of practice in their joint projects. They also developed the concept of situational learning (Lave \& Wenger, 1991). According to these theories, learning is primarily a social phenomenon. Wenger rejects standard, individualized learning, which he believes makes learning dull and too far removed from the context of the world in which we live.

Professional groups meant to improve the teaching of design practices can employ Etienne Wenger and Jean Lave's theories about communities of practice, as well as their research on the development of schools (Wenger, 1998), as each embraces the characteristics of mutual engagement, common activities and common repertoire.

Wenger stresses the importance of long-term communities of practice. He writes that these communities are not meant to provide quick solutions to problems. They should not replace a team or other aspects of an organisation; rather, they should contribute value to the organisation and its members. Wenger, McDermott and Snyder (2002) classify short- and long-term communities of practice in their own definitions. Short-term communities of practice serve as venues for problem solving. They provide quick answers to questions; help improve the quality of decisions and provide wider perspectives on problems. In contrast, long-term communities of practice require the ability to execute a strategic plan, form knowledge-based alliances and establish a forum that facilitates the expansion of skills and expertise (Wenger et al., 2002).

Wenger et al. (2002) write that time is important for someone who is the leader of an organized community. The most common cause of failure is that the coordinator of such a community simply does not make time to perform the role, even when they have allocated time for this purpose; they too easily let other things take priority over community work (Wenger et al., 2002, p. 83).

Several researchers in the field of design and teaching practices use Wenger's theories about communities of practice and the ways in which people learn in groups (e.g., Reitan, 2007; Lutnæs, 2011). Wenger co-developed the book entitled Cultivating Communities of Practice, which focuses on how people can systematically use communities of practice to develop businesses.

\section{Unn Stålsett}

Unn Stålsett is a former Associate Professor at Oslo Metropolitan University, where she worked in classroom teacher education. She describes networking teams in her book, Veiledning i en lærende organisasjon [Guidance in a Learning Organization] (Stålsett, 2006, our translation from Norwegian), which serve as a venue which serve as communities where members can share experiences, make use of one another's knowledge and be open about the challenges they experience in their disciplines. Such groups are not meant to serve as courses in which the participants are passive recipients; rather, everyone is expected to contribute his or her own knowledge.

Unn Stålsett (2006) relies on Wenger and Lave's concepts to discuss methods of learning in a practice community in her book. Based on three features (mutual engagement, common activities and common repertoire), the professional groups in each municipality can be defined as communities of practice. The groups consist of teachers who teach the same subject. Every teacher works within the same municipality, which has a common proficiency development program for each of its schools. The teachers use similar terminologies. 


\section{Starting and managing professional groups in Design, Art and Crafts}

Design, Art and Crafts professional groups were started in Municipality 1 in 2003, as a collaboration between a university and the municipality. The collaboration was managed by Unn Stålsett and an adviser in education for the municipality. Municipality 1 has professional groups for every subject taught in its schools; teachers meet in their groups five times a year for three hours per session (1-4pm). Examples of work done in these professional groups include discussions, relevant political work, workshop activities, excursions, evaluations and visits from external professional speakers. The groups also collaborate with the university to provide guidance for newly educated teachers, as was done at Oslo Metropolitan University's Department of Art, Design and Drama, where new teachers were guided through discussions about innovation and professional development around the theme of assessment practices.

While in Municipality 2, one of the Design, Art and Crafts teachers started a professional group on her own initiative, without any support from the municipality. These differences will be further discussed in next section.

\section{Points of view from advisers, managers and teachers in Municipalities 1 and 2}

In the interviews, the teachers, advisers of the municipalities and managers of the groups had interesting perspectives on the need for collaboration and professional groups.

The adviser of education in Municipality 1 spent approximately half of her interview discussing the subject group managers-she trusts their expertise in their subjects. She could not comment on the actual quality of the groups' content, but she referred to the evaluations done by the professional groups in which it was made clear that the teachers were largely satisfied. In the conversation, she equated Design, Art and Crafts with other subjects and spoke as though it were a matter of course that there was a professional group in Design, Art and Crafts, in line with the other subjects (Brodshaug, 2016).

The adviser of education in Municipality 1 said, "It would have been absolutely crazy if we were to only have professional groups in other school subjects and not in the Design, Art and Crafts subject. We have had that right from the start" (Brodshaug, 2016). She went on to say, "It is important to have a good group manager then, who knows the subject and who is also interested in the development". The interviewer then inquired if a group manager should be able to pull certain strings. The adviser of education replied, "Yes, it is a key role in being a good group manager. I think so far that, in Design, Art and Crafts especially, we have had very good group managers" (Brodshaug, 2016).

In Municipality 2, the adviser of education had heard of the professional group that was started through the initiative of individuals. She said it was a shame that political guidelines meant that they could not prioritize the organization of these groups. She said that politicians prioritize only subjects such as mathematics, foreign language and science. The manager of the professional group in Municipality 2 was asked why she started this group and why she believed it was important. She said that she had worked nearly ten years as a teacher in Design, Art and Crafts at a secondary school where she often collaborated with two other teachers in the same field. When she began work in Municipality 2 in 2006, she was the only teacher in Design, Art and Crafts at her school. She had little relevant development time and was alone in her pursuit of the subject. She wanted to work more closely with other teachers in order to assure the quality of her teaching, ensure better academic progression for her students and discuss pertinent challenges with other Design, Art and Crafts teachers. She contacted her principal and asked if she could invite colleagues within the municipality to spend some of their development time on professional groups. The principal in her school took this further during the municipal principals' meetings and the other principals responded favourably to the idea (Brodshaug, 2016).

The manager of the professional group in Municipality 1 has received allocated time for group planning from the adviser of education. The manager in Municipality 2 must use her own spare time for pre- and post-group work. The quality of work done in Municipality 1 may not be better simply because more time is allowed for planning, however, groups in Municipality 2 are more vulnerable because they do not have time set aside for group work and they do not have a budget for lecturers or excursions. Wenger et al. highlight the importance that the group manager or coordinator have a good individual 
relationship with every member of the practice community (Wenger et al., 2002), which also requires time and good organization.

\section{The focus on prepared, sustainable design proficiency}

In recent years, a primary focus of the professional group of Design, Art and Crafts teachers in Municipality 1 has been to continuously develop design and crafts courses. The group worked in cooperation with an upper secondary school on a project called En ny håndverksvei for barn og unge [A New Pathway to Crafts children and young people]. Together, they designed and made products, such as a chessboard (Figures 1 and 2), from a variety of wood materials. They focused on developing the design process, quality assurance, knowledge of tools, areas of application and an understanding of the best ways to teach students the importance of sustainable materials and techniques. The high dropout rate of students in upper secondary school in Norway is widely known and only a few students choose to study design and crafts. By collaborating with upper secondary schools and focusing on design and crafts in primary and lower secondary schools, the professional group hopes to increase student interest in design and crafts studies in upper secondary schools. It is therefore important to strengthen teaching effectiveness of Design, Art and Crafts from as early as the first grade. The group also wishes to focus on the use of local materials and promote sustainable development. In future years, the professional group will continue to work on these issues in a systematic way (Brodshaug, 2016).

The professional Design, Art and Crafts groups in Municipalities 1 and 2 are organized differently. Municipality 1 has an adviser who has been collaborating with a university, managing the professional groups and taking primary responsibility for all implementation and decisions regarding group managers. She has also been responsible for coordinating group manager meetings, setting aside meeting times and allocating funds. A substantial system has been built around these professional groups, which serve as the municipality's continuing education program for each individual teacher. The professional group for Design, Art and Crafts is equal to the professional groups of other subjects with regard to time and resources allocated when it comes to external course organizers and excursions. There is no similar system in place for these professional groups in Municipality 2. Nevertheless, much of the group content is the same; the groups work on the issues surrounding their subject areas in a similar manner to Municipality 1 (Brodshaug, 2016).

In 2017, the Norwegian Minister of Education spoke at the Design, Art and Crafts Conference at Oslo Metropolitan University (Isaksen, 2017). He stated that the academic community should be strengthened and systematised for the betterment of Design, Art and Crafts as a field of study. In an interview, Thomas Nordahl, a foremost Norwegian academic on school development, underscored that systematically working with others to address challenges in schools is the most important factor that affects school development (Amundsen, 2015). Erling Lars Dale, another academic on school development, promotes the establishment of a collegial community as a condition that strengthens the professional quality of schools. Dale writes that if teachers want to experience meaningful cooperation, they should have a collective identity that is in accordance with their frame of reference (Dale, 1993). These ideas can be linked to Stålsett's theories on network building and Wegner's theories on communities of practice. Over time, communities of practice - such as professional groups and networks with strategic plans for the development of teachers in, for example, design literacy in primary and lower secondary schools - will be important in strengthening the field of design in general and ensuring both teacher and student competency. 

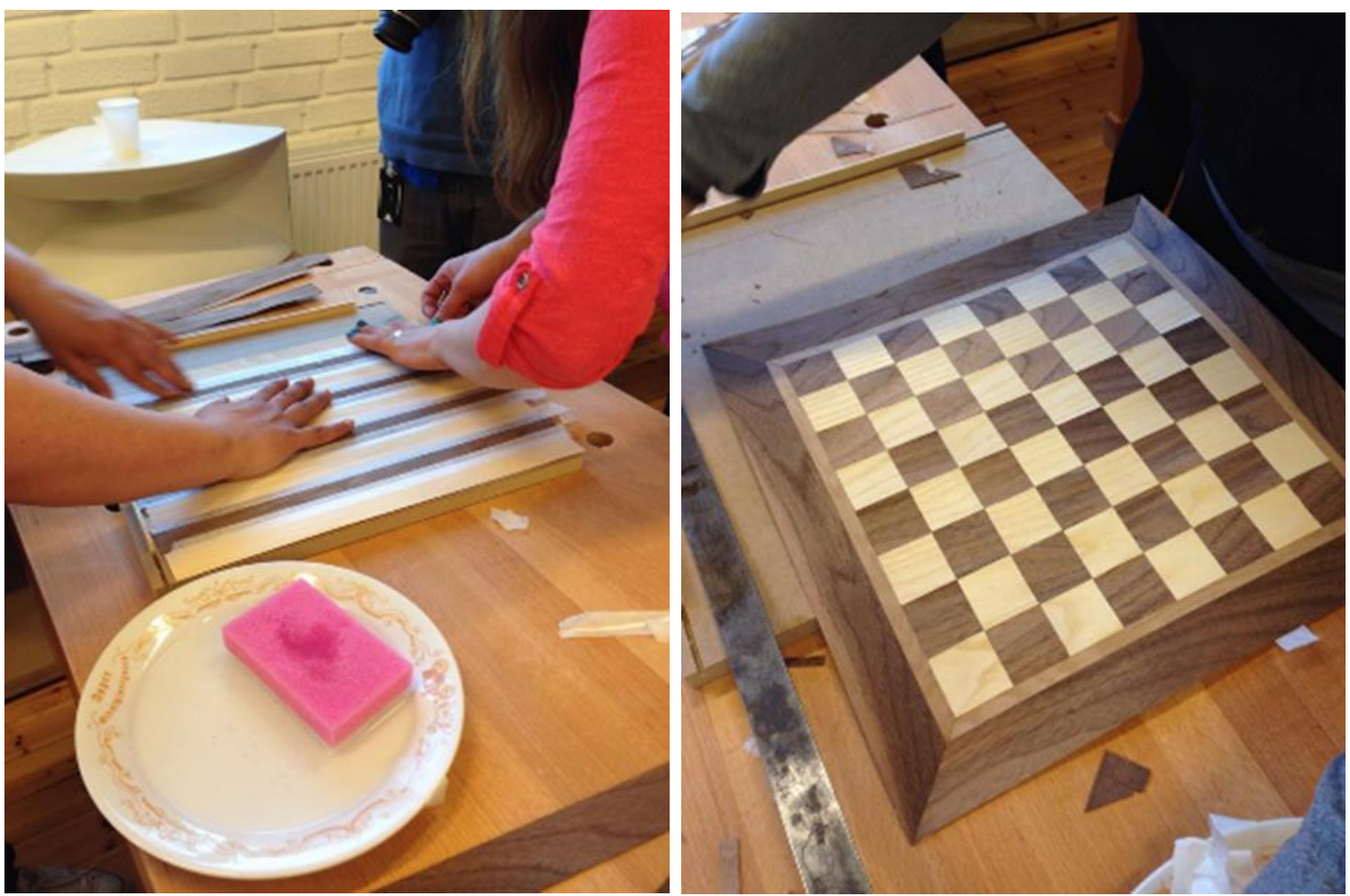

FIGURES 1 AND 2. Designing the chessboard as a team

As Kjosavik et al.'s (2003) report demonstrates, and as many others express in different forms on social media, teachers in Design, Art and Crafts often work independently at their schools. Many miss the opportunity to develop themselves professionally alongside others or to obtain help and advice. This situation is related to the fact that only one-half of Design, Art and Crafts teachers are educated in the subject, although many are educated teachers with backgrounds in other subjects. Facebook groups and other social media forums discuss the subject of Design, Art and Crafts and, through them, it is possible to see a demonstration of Wenger's theories on short-term value communities. These groups become venues for providing quick solutions because group members can easily ask for help and advice. These groups are certainly useful, but teachers should still develop themselves over time and should have a plan for sharing and strengthening their knowledge in the context of a group in order to form strong academic communities.

This study focuses on facilitating collaboration among teachers using professional groups. What does a year of networking through professional groups in the subject Design, Art and Crafts look like for teachers? What should the content of these groups be?

In their employment contracts, teachers in Norwegian schools have time designated both for teaching and for proficiency development. The teachers' total work tasks are performed across 1,687.5 hours per year. Good communication at all levels and systematic collaboration between teachers is important in order to develop processes that meet the individual school's need to organize work hours according to the agreement between Utdanningsforbundet [the Union of Education] and Kommunenes Sentralforbund (KS) [The Federation of Municipalities]. Teachers in Design, Art and Crafts are responsible for 948 lessons (in a full-time equivalent position) per year (SFS 2013, 2015). During the year, municipalities and schools have control over the ways in which teachers organize their teaching time both during and after work, their continuing education and their meeting times.

In a municipality or area containing different schools, there will be teachers who have different skills in different areas. For example, some will have expertise in design literacy and sustainability, while others will have experience working with textiles or wood. If a system can be created that allows teachers to share and learn from each other, then, in a few years, the overall competence of these 
teachers will increase through collaborations with colleges and professional designers that facilitate development of new skills and expertise.

This study shows that it is important that municipalities organize their subject groups in a structured way based on theory and research. It is important that the groups do not become simply a collection of people who meet to obtain a new course or that the teachers become passive participants. Instead, participants should share knowledge and create alliances (Wenger et al., 2002). It is also important that these networks be firmly rooted within both the schools and the municipality so that the groups do not become vulnerable for permanent existence of groups, which should not have to depend on enthusiasts (Brodshaug, 2016).

\section{CONCLUSION AND THE WAY FORWARD}

In order to construct a good foundation for students early on, teachers need sufficient time to become proficient in their subject areas and to develop their field of study in collaboration with other teachers and institutions. If students are to experience progress at their education, and if the quality of teaching design is to be improved, teachers must have a common understanding of teaching standards. In addition to collaboration between schools, teachers in the field of Design, Art and Crafts should work together with colleges and other institutions in order to acquire relevant research insights into the field. Municipality-based professional groups can help a teacher develop competence and can improve design literacy. This is especially true if the municipalities are able to contribute to the organization and structure of these groups.

The research shows that even though teachers can experience greater freedom and influence on networks or professional groups that they have started themselves, municipality involvement is necessary to structure and organize these networks in order to achieve consistent quality and researchbased standards over time. The last part of this article will focus on the ways in which this study can be further developed through work in a third municipality.

\section{The design of professional groups in a third municipality in Norway}

In a third municipality in Norway - a big city - political leaders agree that design expertise should be strengthened to improve the teaching of practical Art and Crafts.

The municipality's Education Agency wishes to start professional groups for Design, Art and Crafts teachers according to the methods and models of Unn Stålsett, Municipality 1's experiences and the research referred to in this article (Brodshaug, 2016). In this context, it is appropriate to consider Wenger's theories on the value of long-term communities of practice. As stated earlier in this paper, these networks should not simply be a collection of people or courses where one can obtain quick answers. These networks should be a place where teachers develop strategies and knowledge-based alliances and where they help to develop their field more broadly.

The goal of each professional group is to strengthen the study of Design, Art and Crafts throughout their municipality, while also improving the design literacy of their teachers. These teachers should be competent in all aspects of the curriculum in order to properly support the learning of their students. Teachers in the municipality have different backgrounds, skills and experiences. Based on a political order, the Education Agency has established a specialist committee and developed proposals designed to strengthen the teaching of certain school subjects, including the creation of professional groups. This step is justified by the findings from different Education Agency surveys, which state that:

- There are few Design, Art and Crafts teachers at each school, and it is therefore challenging to develop professional communities.

- There is a need to increase the competency of teachers, as determined by a mapping of practical subjects completed in spring 2017. In addition to ordinary courses, specialist committees recommend increasing this competence through the exchanging of experiences, the training of one another and the possible hiring of external course organizers. This would be organized and carried out by professional networks. 
Both nationally and locally, government agencies and educational departments have stated that both practical and aesthetic school subjects should be strengthened. In Norway, there is a strong focus on professional development in Fagfornyelsen [The curriculum revision] (Utdanningsdirektoratet, 2018, our translation from Norwegian). The subject renewal states:

All employees in the school must take an active part in the professional learning community in order to further develop the school. This means that the community reflects on value choices and development needs and uses research, experience-based knowledge and ethical assessments as the basis for targeted measures. Well-developed structures for collaboration, support and guidance between colleagues and across schools promote a sharing and learning culture. (Utdanningsdirektoratet, 2018, our translation from Norwegian)

Professional groups can contribute to the systematisation of competence development, the structure of a subject's content and the strengthening of the professions and the students' learning in that subject. In order to succeed, these networks must be based on theory and research and they must be structured and managed in a planned manner. In October 2018, an establishment meeting was held with three teachers from different primary and secondary schools in Municipality 3 to launch professional networks. The three teachers had a high level of expertise in art, crafts and design. Their goal is to be the managers of these professional groups and to use different strategies to increase the competency of teachers and strengthen the study of these subjects in their schools. These potential managers work in different schools throughout the city and intend to coordinate teachers from approximately 25 schools, who will meet to develop their competence. In total, there will be three different professional groups involving approximately 75 teachers.

To strengthen the design literacy of teachers and students in Municipality 3, the region should focus on several things referred to in this article. The managers will collaborate on developing an organizational structure and determining desired content in 2019.

The first gathering of Municipality 3's professional groups took place in March 2019. Their goal was to meet the teachers and discuss the importance of both Design, Art and Crafts and good design education. These groups will focus on design and sustainable development. They will eat together, talk together and map out the competence of the group using Stålsett's model (2006). They will ask the teachers which subject areas they are competent in and how they can share that competency with the group. For example, a teacher with a strong design education could lead initiatives and instruct others in the group on that topic.

In the second session, to be held in June 2019, the three professional groups will gather at a university in Municipality 3 where professionals, designers and professors will contribute to the teachers' education. Afterwards, design education and the development of teacher competence will be discussed. In autumn 2019, another gathering will focus on workshops and knowledge sharing; different teaching methods, crafts, materials and skills will be important topics. The new national curriculum, subject renewal and sustainability development will be highlighted. The overarching goal is to engage professional teachers who are passionate about their subject matter, so that students learn more and develop increased curiosity in these areas. These meetings will also focus on working together to recruit others to the field of education. Finally, professions that emphasize design will be an important topic at these meetings.

The goal is to achieve the best possible community of practice to strengthen the teaching profession so that students can receive better design education and become design literate, a skill that will be ever more valuable as we work toward a sustainable future. 


\section{REFERENCES}

Alvesson, M., \& Sköldberg, K. (2009). Reflexive methodology: new vistas for qualitative research (2nd ed.). Sage.

Amundsen, B. (April 2015). Sånn fär vi en god skole, mener skoleforskeren [How we get a good school, states the school researcher]. http://forskning.no/samfunn-barn-og-ungdom-samfunnskunnskap-skole-ogutdanning/2015/04/sann-far-vi-god-skole-mener.

Brodshaug, I. (2016). Faggrupper for lærere i kunst og håndverk-Innhold, organisering, og nytteverdi [Professional networking groups for teachers of Design, Art and Crafts-Content, organization, and utility] (Master's thesis, Høgskolen i Oslo og Akershus [Oslo and Akershus University College]). http://hdl.handle.net/10642/3335.

Dale, E.L. (1993). Den profesjonelle skole [The Professional School]. Ad Notam Gyldendal.

FormAkademisk (2021). Focus and Scope. https://journals.oslomet.no/index.php/formakademisk/about

Garberg, M. (2014). Planer-hva og hvorfor? En undersøkelse av innholdet i de lokale læreplanene i kunst og håndverksfaget på barneskolens mellomtrinn [Plans-What and Why? An Examination of the Content of the Local Curricula in the Design, Art and Crafts Subject in Primary Schools] (Master's thesis, Høgskolen i Oslo og Akershus [Oslo and Akershus University College]) http://hdl.handle.net/10642/2117.

Hansen, B.H. (2015). Trearbeid og treverksteder i grunnskolen [Woodworking and wood workshops in primary school] (Master's thesis, Høgskolen i Oslo og Akershus [Oslo and Akershus University College]. http://hdl.handle.net/10642/2712.

Isaksen, T.R. (January 2017). Åpning av kunst-og håndverkskonferansen 2017 [Opening Speech at the Design, Art and Crafts Conference 2017]. https://film.hioa.no/apning-av-kunst-og-handverkskonferansen-2017.

Kjosavik, S., Koch, R.H., Skjeggestad, E., \& Aakre, B. M. (2003). Kunst og håndverk i L97 - Nytt fag ny praksis? [Design, Art and Crafts in L97-New Subjects, New Practice?]. Telemarksforskning. http://hdl.handle.net/11250/2439965.

Kunnskapsdepartementet [Ministry of Education]. (2006). Læreplan i kunst og håndverk [Design, Art and Crafts curriculum]. Utdanningsdirektoratet [The Norwegian Directorate for Education and Training]. Retrieved https://www.udir.no/kI06/KHV1-01/Hele/Kompetansemaal/etter-10.-arstrinn.

Kunnikoff, J.O. (2015). Formell fagkompetanse i kunst og håndverk. Betydning, prioritering og konsekvenser [Formal expertise in Design, Art and Crafts, Meaning, Prioritization and Consequences] (Master's thesis, Høgskolen i Oslo og Akershus [Oslo and Akershus University College]. http://hdl.handle.net/10642/2658.

Lagerstrøm, B.O., Moafi, H., \& Revold, M.K. (2014) Kompetanseprofil i grunnskolen Hovedresultater [Profile of Skills in Primary Schools, Main Results], 2013/2014. Statistisk Sentralbyrå. https://www.ssb.no/utdanning/artikler-og-publikasjoner/_attachment/197751?_ts=148a1618d30.

Lave, J., \& Wenger, E. (1991). Situated learning: legitimate peripheral participation. Cambridge University Press. https://doi.org/10.1017/CBO9780511815355

Lie, C. (2013). Skolelederes verdsetting av læreres fagkompetanse i kunst og håndverk [School Leaders' Valuation of Teachers' Professional Skills in Art and Craft] (Master's thesis, Oslo Høgskolen i Oslo og Akershus [Oslo and Akershus University College]. http://hdl.handle.net/10642/1620.

Lie, C., \& Nielsen, L.M. (2016). Lærernes arbeidstid i Kunst og håndverk-grunnlaget for gammeldags leseplikt i grunnskolen [Teachers scheduled classes in the subject Art and Crafts-The background for the existence of an outdated teaching load in lower secondary school]. FormAkademisk-Research Journal of Design and Design Education, 9(2). https://doi.org/10.7577/formakademisk.1845.

Lutnæs, E. (2011). Standpunktvurdering i grunnskolefaget kunst og håndverk. Læreres forhandlingsreportoar [Final Evaluation Grades in the Subject of Design, Art and Crafts the Teacher's Negotiation of Repertoire] (PhD thesis, Arkitektur-og designh øgskolen i Oslo [Oslo School of Architecture and Design]. http://hdl.handle.net/11250/93051.

Nielsen, L.M. (2008). Art, design and environmental participation. Norwegian research in art and design education 1995-2006. In L. Lindström (Ed.), Nordic Visual Arts Education in Transition. A research Review. Svenska Vetenskapsrådet. 
Nielsen, L. M., \& Brænne, K. (2013). Design literacy for longer-lasting products. Studies in Material Thinking 9, 19. https://www.materialthinking.org/papers/125

Pacione, C. (2010). Evolution of the mind: A case for design literacy. Interactions, 17(2), 6-11. https://doi.org/10.1145/1699775.1699777

Regjeringen [The Government] (2015). Kompetanse for kvalitet [Competence for quality]. Kunnskapsdepartementet [Ministry of Education]. https://www.regjeringen.no/no/dokumenter/kompetanse-for-kvalitet/id2439181/.

Reitan, J. B. (2007). Improvisation in tradition: a study of contemporary vernacular clothing design practiced by Iñupiaq women of Kaktovik, North Alaska (PhD thesis, Oslo School of Architecture and Design). http://hdl.handle.net/11250/298633.

SFS 2213. (2015). Særavtale for undervisningspersonalet i kommunal og fylkeskommunal grunnopplæring. [Special agreement for teaching staff in municipal and county municipal primary education]. https://www.utdanningsforbundet.no/upload/Tariff/Lonn_Arbeidsvilkaar/KS/Endelig_protokoll_vedlegg.pdf.

Simon, H. A. (1969). The sciences of the artificial (Vol. 136). Massachusetts Institute of Technology.

Smith, R. C., \& Iversen, O. S. (2018). Participatory design for sustainable social change. Design Studies (59), 9-36. https://doi.org/10.1016/j.destud.2018.05.005.

Stålsett, U. (2006). Veiledning i en lærende organisasjon [Guidance in a Learning Organization]. Universitetsforlaget.

Utdanningsdirektoratet [The Norwegian Directorate for Education and Training]. (2018). Profesjonsfellesskap og skoleutvikling [Professional community and school development]. https://www.udir.no/laring-ogtrivsel/lareplanverket/overordnet-del/prinsipper-for-skolens-praksis/profesjonsfellesskap-ogskoleutvikling/.

Wenger, E. (1998). Communities of Practice. Cambridge University Press. https://doi.org/10.1017/CBO9780511803932

Wenger, E., McDermott, R., \& Snyder, W. (2002). Cultivating Communities of Practice. Harvard Business School.

\footnotetext{
${ }^{1}$ First published as Brodshaug, I. \& Reitan, J. B. (2019). Networking for strengthening design literacy. Conference Proceedings of the Academy for Design Innovation Management, 2(1). The article is republished with permission.
} 